\title{
6
}

\section{Boosting Education}

\begin{abstract}
In this chapter Cilliers provides an overview of trends in education in Africa and compares that with progress in other regions. In addition to a review of common educational outcomes such as measuring years of schooling, he places attention on the poor quality of education and roles of gender exclusion. That is followed by a summary of future education requirements and a scenario, Boosting Education, that explores the impact of improvements in the quality and quantity of education in Africa while taking advantage of technology to promote learning outcomes and human development.
\end{abstract}

Keywords Education - Education systems - Literacy · Skills · Future of work $\cdot$ Education policy $\cdot$ Education technology $\cdot$ Gender parity $\cdot$ Basic education · Vocational training

\section{Learning Objectives}

- Explain the reasons for poor educational outcomes in Africa

- Recognise and explain the key metrics for measuring education outcomes (e.g. enrolment and completion rates, gender parity)

- Understand why a focus on basic education and the use of technology in education are central to improving education outcomes in Africa

Education lies at the foundation of human development and self-attainment. It enables us to lead a self-determined existence, to increase professional performance and to improve our health. It is the reason successful modern 
societies are called knowledge societies. Governments, world leaders and NGOs across the world, literally all of humanity with the exception of terror and extremist organisations such as the Islamic State, Al-Qaeda and Boko Haram are all in favour of more, better and broad-based education for men and women.

Education and prosperity go hand in hand. Whereas the average years of adult education in low-income countries is just below five years, in lowermiddle-income countries it is more than seven years, in upper-middle-income countries it is almost nine years, and in high-income countries it is twelve years.

The accepted economic wisdom is that investments in education increase the talent in the labour pool, raise productivity and boost economic growth and incomes. Let's refer to this as a supply-side model, where parents, governments and others invest in education in the belief that it will improve the chances of well-paying jobs for their children (and themselves) and generally a better quality of life.

A study from Eric A. Hanushek and Ludger Woessmann found that each year of additional school is associated with a nearly $0.6 \%$ increase in longterm gross domestic product (GDP) growth rates. ${ }^{1}$ And many studies have linked the economic boom that followed in the United Kingdom and the USA after the Second World War to the advent of mass public education before the First World War. ${ }^{2}$

But could it not be equally plausible that a growing economy requires and therefore incentivises education? In other words, is it demand that drives improved education outcomes? According to this line of reasoning, the potential for better employment drives educational improvements above a certain basic level.

China, for instance, only introduced the Law on Nine-Year Compulsory Education in 1986 at which point the Chinese economy was already averaging more than $10 \%$ growth per annum. At that point, compulsory education could build on adult literacy rates that were at roughly $72 \% .^{3}$

\footnotetext{
${ }^{1}$ Hanushek, E. A., and Wößmann, L., 2010. Education and Economic Growth. In: P. Peterson, E. Baker, and B. McGaw, eds. International Encyclopedia of Education. volume 2. Oxford: Elsevier, pp. 245-252.

${ }^{2}$ Morris, P., 1996. Asia's Four Little Tigers: A Comparison of the Role of Education in Their Development. Comparative Education, 32(1), pp. 95-109.

${ }^{3}$ Education in China has evolved so rapidly that today it is the second most popular destination for African students studying abroad, after France. Mo Ibrahim Foundation, Africa's Youth: Jobs of Migration?, Mo Ibrahim Foundation, 2019. Africa's Youth: Jobs or Migration? London: Mo Ibrahim Foundation.
} 
So, beyond basic literacy and primary education (the two generally go together), do subsequent improvements in levels of education precede or follow economic development? And, exactly what type and level of education will Africans require for a future characterised by digitisation and the fourth industrial revolution? What needs to be done, and what is practically possible to improve education?

History tells both supply and demand stories. Generally, literacy and highlevels of primary school education attainment is a requirement for countries to graduate from low to middle-income status. However, whereas in Europe and the US rising levels of education foreshadowed development, in Asia improvements in education beyond primary school levels generally accompanied more rapid economic growth. ${ }^{4}$ In the two decades between 1960 and 1980, the East Asia and Pacific region increased the number of average years of education in its adult population by about $80 \%$, and growth in gross domestic product (GDP) per capita tracked closely at about $85 \%$.

However, in the following two decades (from 1980 to 2000) GDP per capita more than doubled from about US $\$ 3500$ per person in 1980 to about US $\$ 7700$ per person. Over the same time period, the number of average years of education in the adult population increased by just one-third. Of course, when coming off a higher base it is not as easy to maintain the previous momentum of improved education as levels approach saturation (or 100\%). But could it not also be the case that educational requirements for the region had largely been met in the first phase of growth, and that the education being provided may not have been well suited to the requirements for further growth?

In practice, the demand model of education therefore reinforces the supply-side model but the latter is clearly the more important of the two. In the supply model, educationalists, governments and parents invest in core knowledge and competencies (traditionally termed reading, writing and arithmetic) and complement that core knowledge by trying to anticipate where more specific opportunities lie. What is in demand today could, of course, change completely by the time students graduate given the inevitable time that it takes to roll out a particular curriculum. And in the twenty-firstcentury demand is changing with each passing decade.

The complexity and level of sophistication of the economy certainly play a particular demand-side role. In general, all economies require a better skilled and more highly educated workforce over time, although countries that specialise in the production and export of unprocessed commodities perhaps

\footnotetext{
${ }^{4}$ See, for example, Roser, M., and Ortiz-Ospina, E., 2018. Literacy. [Online] Available at: https://our worldindata.org/literacy.
} 
less so. Going up the technology ladder towards greater productivity requires constant improvements in knowledge levels. Hence the global trend for a decrease in the demand for unskilled labour and an increase in semi-skilled and skilled labour. ${ }^{5}$

Furthermore, skilled labour and capital also tend to flow from poorer to richer countries rather than the other way around. ${ }^{6}$ This is part of the story of the African brain drain, where well-educated Africans such as nurses, doctors and engineers often seek employment in higher-income countries. In fact, recent data from AfroBarometer confirms that sub-Saharan African nations account for eight out of the ten fastest growing international migrant populations since $2010 .^{7}$ This steady exodus means that the education system in origin countries needs to work twice as hard. ${ }^{8}$

There is little doubt that advancing the average number of years of education in the adult population can give a substantial boost to GDP over the long-run, but improving the general level of education takes time and the economic returns take even longer to materialise. A study by the Education Policy and Data Center ${ }^{9}$ found that it could take as many as 150 years, or seven generations, to move from $10 \%$ adult primary school completion to $90 \%$ secondary school completion. The average length of the transition for the countries in the group was nearly 90 years.

At the same time, the example of South Korea demonstrates that rapid progress is possible. Following a devastating war that split the country into two, the 'Miracle on the Han River' (the nickname for the period of rapid economic growth in South Korea after the Korean War) saw mean years of education triple from four years in 1960 to more than 12 years in 2015 . At this point, South Korea had caught up with established Western democracies like the United Kingdom and surpassed others such as Sweden. It also achieved 42 consecutive years of exceptional primary enrolment rates, affirming the importance of getting the foundation right as part of an investment in the future.

\footnotetext{
${ }^{5}$ Reinert, E.S., 2010. How Rich Countries Got Rich and Why Poor Countries Stay Poor. London: Constable, p. 113.

${ }^{6}$ Ibid., p. 191.

${ }^{7}$ Sanny, J.A.-N., Logan, C., and Gyimah-Boadi, E., 2019. In Search of Opportunity: Young and Educated Africans Most Likely to Consider Moving Abroad. Accra: Afrobarometer Dispatches no 288.

8 This is the view advanced by Swedish economist and Nobel Laureate Gunnar Myrdal. His work preempted that of John Maynard Keynes.

${ }^{9}$ Carrol, B., Barrow, K., and Wils, A., 2005. Educating the World's Children: Patterns of Growth and Inequality. Washington, DC: Education Policy and Data Center. Available at https://www.epdc.org/ education-data-research/educating-worlds-children-patterns-growth-and-inequality.
} 
As countries graduate to middle-income status, the educational system needs to provide additional skills and knowledge that respond, in part, to the anticipated future demand. Therefore the evidence suggests that demand becomes more relevant only after countries have mastered the basics.

\section{Recent Education Trends in Africa}

The negative consequences of Africa's lost decades during the 1980s and 1990 s are difficult to overestimate. Rather than simply sluggish growth, Africa experienced an actual decline in gross domestic income per capita of about $12 \%$ between 1980 and 1990 and another two percent during the 1990s before rebounding by about $30 \%$ in the first decade of the 2000 s.

During this period, the continent also suffered stagnation or, in some instances, a relative decline in average years of adult education compared to other regions. During the 1960s and 1970s adults in sub-Saharan Africa were on average better educated than people in South Asia, by a margin of nearly half a year of schooling. By 1995 South Asia had closed the education gap and by 2018 it had surpassed sub-Saharan Africa by almost a year and a half. In 2018 adults in South Asia could expect to receive about seven years of education compared to just 5.6 years in sub-Saharan Africa. ${ }^{10}$ Again, while things are improving in Africa it is at a slower rate than elsewhere.

The divergence in education between Africa and the rest of the world is driven by a number of factors that relate to rates of economic growth, policy and government expenditure on education, among others. For the purposes of this chapter, three considerations are particularly relevant. The first is the massive annual influx of more and more children into educational systems that are already struggling to deal with overcrowding and often inefficient use of resources. This challenge underlines the importance for Africa to accelerate its demographic transition, as discussed in Chapter 4.

The second consideration is the inability of many African countries to retain students within the education system, i.e. to enable them to progress from one grade to the next and not leave school. The third is about the quality of education, which is discussed separately below.

To understand the challenge of retaining children in school, the second challenge mentioned above, the education system can be viewed as a long funnel, with various cracks and fissures along the way. Children enter the

${ }^{10}$ The numbers in this paragraph relate to the age group above 15 years. 
system at the wider end and graduate with a tertiary or equivalent education at the other end, having lost many of its original entrants along the way.

The inevitable goal of educational systems is to increase the pass rates or number of graduates along the length of the funnel. Once the funnel has changed to become a straight pipeline with no 'leaks', we would have a perfect system where, ideally, the full complement of potential students enter at one end and progress through to achieving relevant higher education at the other end. In Finland, generally considered the country with the best education system globally, the gross intake ratio to the last grade of primary school is basically $100 \%$. For lower secondary education it is $99 \%$, and for upper secondary education is at almost $90 \%$. What this means is that all Finns complete at least lower secondary education and that 10 percentage points of those that enter upper secondary school don't complete it. ${ }^{11}$ Only when one gets to tertiary education is there a substantial drop off in these numbers.

To this end, policymakers should generally focus on steadily widening the width of the funnel from its origin in order to maximise the number of entrants that enter and successfully complete primary education, measured in primary enrolment and completion rates. Put differently, as many pupils as possible should first progress through primary, then on to lower and then to upper secondary levels. This will expand the pool of students at each successive level and is generally the most cost-effective way to proceed since it raises general levels of education throughout society and hence improve skills and potential as part of a comprehensive development strategy.

Africa needs to attack all aspects of the educational funnel to ensure that it retains as many students at every level and enables as many as possible to progress from one level to the next. In a number of countries that we have studied, too much funds and attention is often spent on improving say upper secondary education without also looking at the extent to which the preceding primary and lower secondary school sections of the pipeline constrain progress at upper secondary level.

As shown in Table 6.1, the situation in sub-Saharan Africa is very different compared even to East and Southeast Asia, the Middle East and North Africa (MENA), Latin America and the Carribean and South Asia. Poor outcomes in each column at either enrolment or completion are coded orange and red depending upon the severity compared to the situation in other regions. While not included in the table, the situation at tertiary level is especially problematic.

${ }^{11} \mathrm{http}: / /$ data.uis.unesco.org/. 
Table 6.1 Progress through the education funnel (gross percentages) (2018)

\begin{tabular}{|l|c|c|c|c|c|c|}
\hline & \multicolumn{2}{|c|}{ Primary } & \multicolumn{2}{c|}{ Lower Secondary } & \multicolumn{2}{c|}{ Upper Secondary } \\
\hline & Enrolment & Completion & Enrolment & Completion & Enrolment & Completion \\
\hline $\begin{array}{l}\text { Sub-Saharan } \\
\text { Africa }\end{array}$ & 102 & 75 & 57 & 43 & 37 & 29 \\
\hline $\begin{array}{l}\text { East and South } \\
\text { East Asia }\end{array}$ & 105 & 103 & 99 & 94 & 87 & 73 \\
\hline $\begin{array}{l}\text { MENA } \\
\text { (Middle East } \\
\text { and North } \\
\text { Africa) }\end{array}$ & 105 & 101 & 96 & 82 & 76 & 64 \\
\hline $\begin{array}{l}\text { Latin America } \\
\text { \& Caribbean }\end{array}$ & 106 & 105 & 105 & 83 & 81 & 61 \\
\hline \begin{tabular}{l} 
South Asia \\
\hline
\end{tabular} & 108 & 97 & 86 & 61 & 61 & \\
\hline
\end{tabular}

Source IFs 7.45 initializing from Barro-Lee

The percentages used in Table 6.1 are gross numbers, and can be quite misleading if not placed into context. Gross rates include all students in a grade irrespective of whether or not they are at the appropriate age. Students who are over-age, including students who are repeating the grade, would therefore also be included in the gross rate. The result is that percentages are sometimes above $100 \%$.

The completion rate is the percentage of students aged 3-5 years above the intended age of the last grade of each level of education who have completed that grade. ${ }^{12}$

Had I used the net figure, it would only include students at the appropriate age. For example, the gross enrolment rate for primary school in sub-Saharan Africa in Table 6.1 is $102 \%$ but the net primary enrolment rate (not shown in the table) is only $69 \%$ indicating that a large number of children that are supposed to be in school are not, and that many classes are crowded by older children. Crowded classrooms have a variety of negative consequences that range from a higher pupil to teacher ratio to insufficient desks, books and equipment.

Table 6.1 shows the acute drop from $75 \%$ primary completion to a mere $29 \%$ upper secondary completion rate in sub-Saharan Africa. It is

12 UNESCO, Institute for Statistics, http://uis.unesco.org/en/glossary-term/completion-rate. 
therefore clear that the educational funnel contracts very rapidly in subSaharan Africa-quite different to the situation in North Africa where upper secondary completion rates are at $65 \%$. North Africa is part of the MENA region which is $64 \%$.

Furthermore, educationalists generally distinguish between official enrolment and school attendance rates and numbers. Table 6.1 uses the former. Attendance rates are sourced by asking households directly as opposed to using information pulled from official registration data. In the majority of poor countries enrolment rates are significantly higher than attendance rates as many children who are officially enrolled do not regularly attend school.

Another set of statistics that is used to measure the general level of education in a country is to look at the mean level of education of adults. Figure 6.1 presents the mean years of education for sub-Saharan Africa, North Africa and the mean in the World except Africa in 2018 with the Current Path forecast for 2040. The comparison is done for the age grouping 25 years and older and would look slightly better if one looks at say the cohort of young adults aged 15-24 years of age, or 15-29 years, given the generation gap in education levels evident in much of Africa.

Currently, Eastern/Horn of Africa has the lowest level of educational attainment among the five regions in Africa, but it overtakes Central Africa by 2040, with Seychelles, Mauritius and Kenya doing particularly well. Southern Africa presently has the highest levels of adult education but will be overtaken by North Africa by 2040 .

The main reason for Southern Africa's slow rate of improvement is that the level of adult education in South Africa is forecasted to remain stagnant

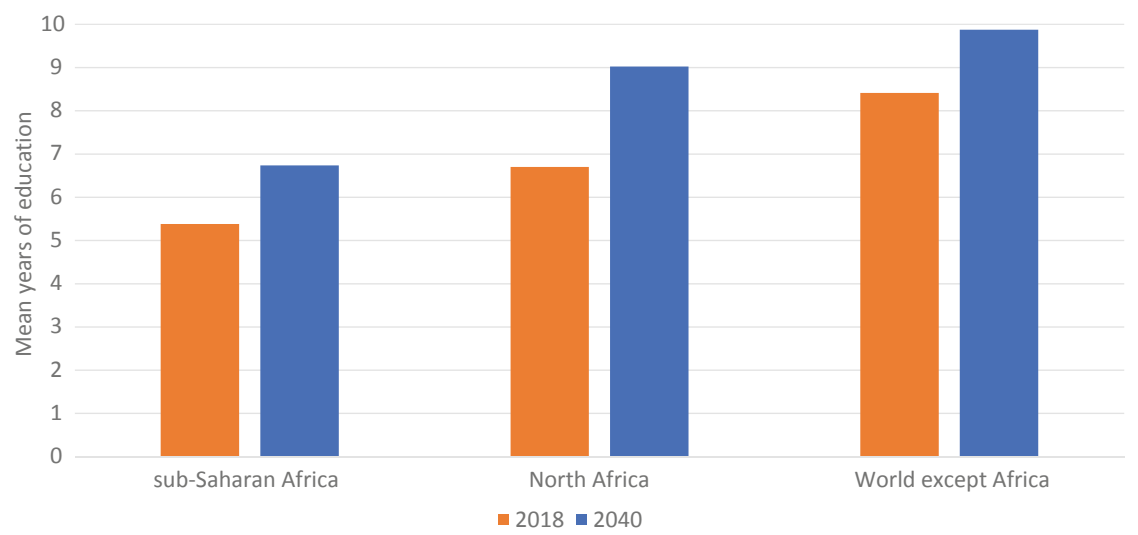

Fig. 6.1 Current Path forecast of mean years of education (25+ age group) (Source IFs 7.45 initializing from United Nations Population Division medium term forecast and Barro-Lee educational attainment dataset) 
while those in Angola could even deteriorate slightly. This is an alarming forecast for South Africa, the economic giant in the region, as it finds itself in a demographic sweet spot for growth with a ratio of 1.9 working age persons to dependents (discussed in Chapter 4).

South Africa is often used as an example of how to get education wrong. For two decades after Nelson Mandela was elected president in 1994 the country served as a guinea pig for educational experimentation. For example, the early dismantling of the country's separate teacher colleges in favour of standard university teaching dealt teacher education a blow from which it is only now starting to recover. In addition, extensive unionisation of the teaching profession resulted in a situation where union leadership practically ran schools with reports of positions, such as the head of a department or school principal being sold. Effective systems such as independent inspections have been dismantled in favour of self (i.e. union)-regulation. There are recent signs of progress, but that is of little consolation for a population that was expecting more.

Bad policies, poor management and corruption in the governing African National Congress have prevented South Africa from benefiting from its remarkable transition from apartheid. Instead of focusing on getting the basics right, the rush to apply imported educational models with limited regard for the local context has meant that education has improved at a rate significantly lower than its potential. ${ }^{13}$ South Africa is also forecast to grow slowly, and slow growth translates into limited revenues to invest in education, implying that future options are limited.

\section{Comparing Education in Africa with Other Regions}

At this point in time, no region in Africa is on par with average levels of education in the second-lowest region for attainment globally, South America. Only Northern Africa will probably surpass South America's 2018 level by 2040 . This is not a pretty picture.

The contrast with average levels of adult education in North America, which is already at above 12 years in 2018, is even more stark. Whereas the average adult in North America has completed upper secondary school, the average adult in Central, East and West Africa does not have the equivalent of primary schooling.

13 The best example is the experiment with so-called Outcomes Based Education. 
There is progress to the extent that the level of education in Africa among young people aged 20-29 years is often much higher than that of their parents. Africa therefore also has a large intergenerational gap. The literacy and education rates for the youngest population group in poor countries can be up to three times higher than it is for the oldest population group. ${ }^{14}$

These large differences in outlook and expectations inevitably translate into discontent and even violence. A prime example is the Arab Spring in North Africa, where the protests were generally led by younger, well-educated groupings, many of whom were unable to find formal sector jobs in economies stifled by state bureaucracy and corruption.

The gap in adult educational attainment between Africa and other developing regions is forecast to widen in the Current Path forecast. By 2030, IFs forecasts that people in South Asia can expect to receive about 8 full years of education while people in sub-Saharan Africa will only achieve about 6.2 years.

This trajectory means that it is highly unlikely that Africa will be able to meet the primary school education target of the Sustainable Development Goals (SDGs). Target 4.1 intends that all girls and boys have access to 'free, equitable and quality primary and secondary education', as measured by a minimum proficiency in mathematics and reading. ${ }^{15}$ In fact, in the Current Path forecast only about two-thirds of African adults will have completed primary school in 2030 while just half of the continent's population will have completed lower secondary school.

\section{The Low Quality of Education in Africa}

According to research published by Erik Hanushek and Ludger Wössmann for the World Bank in 2007, ${ }^{16}$ there is a stronger correlation between educational quality and economic growth than between educational quantity and growth. This makes intuitive sense, as attending class does not automatically guarantee that one will learn something!

It's therefore not as much the quantity of schooling, as measured by mean years of education at various age levels, that is important, but more the quality of education that is being provided. According to the authors, 'expanding

\footnotetext{
${ }^{14}$ Roser, M., and Ortiz-Ospina, E., 2018. Literacy. [Online] Available at: https://ourworldindata.org/ literacy.

15 United Nations, 2018. Sustainable Development Goal 4. [Online] Available at: https://sustainabled evelopment.un.org/sdg4.

${ }^{16}$ Hanushek, E. A., and Wössmann, L., 2007. Education Quality and Economic Growth. Washington, DC: The World Bank.
} 
school attainment, at the center of most development strategies, has not guaranteed better economic conditions. What's been missing', they write, 'is ... ensuring that students actually learn'. ${ }^{17}$ Fortunately, a number of international standardised tests that have been developed in recent years help to systematically measure learning outcomes at the primary and secondary school levels across countries. ${ }^{18}$

We know that learning starts slowly in low-income countries, where preschooling is mostly non-existent, and even students who make it to the end of primary school often do not master basic competencies. Research has found that the average primary school student from a low-income country, would be singled out for remedial attention on the basis of being below standard should he/she attend primary school in a high-income country! ${ }^{19}$

In sub-Saharan Africa, less than half of students meet the minimum proficiency threshold that is used in the standardised testing, whereas the mean for developed countries is at $86 \% .{ }^{20}$ To put that in comparative context-when it comes to learning outcomes 'the top-performing country in sub-Saharan Africa has a lower average score than the lowest-performing country in Western Europe'. ${ }^{21}$ It is, therefore, not surprising that the World Bank in 2017 warned of a 'learning crisis in global education'. ${ }^{22}$ The report presented an analysis of reading, mathematics and science outcomes and the results for sub-Saharan Africa making for disheartening reading.

Although school attendance is generally good in the region, many children suffer from illness, malnutrition and/or income deprivation. Since teachers are often not particularly well educated themselves, the quality of teaching is poor, while absenteeism among teachers is rife. Many pitch up at school, but then don't attend the class they are supposed to teach. Some even engage in a second (or third) job to support themselves and their families. Since schools

\footnotetext{
17 Ibid., p 1.

18 A recent dataset has created a common measurement system for 163 countries including 30 in subSaharan Africa. Altinok, N., Angrist, N., and Patrinos, H. A., 2018. Global Data Set on Education Quality (1965-2015). World Bank Group Policy Research Working Paper 8314, January.

19 Ibid., p. 5. The findings from Altinok and colleagues are that: 'learning outcomes in developing countries is generally clustered at the bottom of the global scale and even the top developing country performers still often perform worse than the bottom performers in developed countries'.

20 Ibid., p. 23.

21 Ortiz-Ospina, E., 2018. Global Education Quality in 4 Charts, Our World in Data. [Online] Available at: https://ourworldindata.org/edu-quality-key-facts.

22 The World Bank, 2018. World Development Report 2018: Learning to Realize Education's Promise. Washington, DC: The World Bank Group.
} 
are short-staffed, those teachers who do attend to their duties are inundated with administrative tasks. ${ }^{23}$

For the World Bank, the immediate causes of the crisis are fourfold: children arrive unprepared to learn (generally children from poor households learn much less); teachers often lack the skills or motivation to teach effectively; inputs like books and teaching material often fail to reach classrooms or to affect learning and poor management and governance often undermine schooling quality. ${ }^{24}$

\section{Rates of Gender Exclusion}

Changing gender parity in education - the number of female students participating in a given level of education relative to the number of male students at the same level-is another important milestone on the road to improved education.

In sub-Saharan Africa, gender parity in education has improved over time but still trails behind regions such as the Middle East and North Africa (MENA) that often have a bad reputation when it comes to the rights of girls and women. In sub-Saharan Africa the average woman aged 25 years and above has received about 4.6 years of education compared to 5.8 years for every male. The gap is slightly smaller when extending the cohort to women and men aged 15 years and above where the mean is at 5.2 years versus 6.1 years, again indicating the extent to which younger Africans are better educated than their parents. In the MENA region female adults aged 25 and above have more than seven years of education and those aged 15 and above almost eight.

Improving levels of educational attainment is a slow process. Leaving quality aside it took sub-Saharan Africa 14 years, from 2001 to 2015, to increase the average number of years of education of women by one year. The global mean for years of adult female education stands at 7.9 years-a goal sub-Saharan Africa will only achieve after mid-century on the Current Path, at which point the global average will likely have increased to about 10 years. On the Current Path there is no indication of Africa closing this gap under current conditions.

\footnotetext{
23 Sow, M., 2018. Figures of the Week: Africa, Education, and the 2018 World Development Report. [Online] Available at: https://www.brookings.edu/blog/africa-in-focus/2017/10/06/figures-of-the-weekafrica-education-world-development-report-2018/.

${ }^{24}$ The World Bank, 2018. World Development Report 2018: Learning to Realize Education's Promise. Washington, DC: The World Bank Group, pp. 9-11.
} 
In 2015 in sub-Saharan Africa, 95 girls attended primary school for every 100 boys, a ratio that worsens significantly at secondary school level (only 90 girls for every 100 boys) and decreases to 73 women for every 100 men that enrol in tertiary education. In four countries (Liberia, the Democratic Republic of the Congo, Mozambique and Niger), adult women have less than half the mean years of education compared to males.

Compare that to the situation in South America where the average woman aged 25 and older will have received about the same number of years of education as their male counterparts, while in East Asia, Central Asia and Europe the gap between the mean for male and female levels of education vary between about 0.9 and 0.97 years. So in these regions women still get less education compared to men, but are rapidly approaching equality. Of the regions explored in this book, only women in South Asia (with a gap of 2.6 years between the mean for men and women) face higher barriers to educational attainment than in Africa. Given the link between female education and fertility, this large difference to a great degree explains Africa's very high fertility rates as discussed in Chapter 4.

\section{Africa's Future Education Requirements}

Before proceeding to the development of an improved education scenario and an analysis of its associated impact, we must first ask ourselves what future Africa's students need to be prepared for.

A recent study from the African Development Bank found that three main factors constrain more rapid job creation in Africa. First, job creation has not kept pace with the number of graduates from secondary and tertiary institutions. Second, those who finish school are not equipped with the skills required in the available jobs. Finally, young people generally lack the soft skills, social networks and professional experience to compete with older job applicants. $^{25}$

In its study on the future of work in Africa, the Ghana-based African Center for Economic Transformation is more specific:

There is far too little emphasis on relevant training in science, technology, engineering, and math; on technical and vocational education and training; and on higher-order cognitive and analytical skills. Hence, the considerable skills

\footnotetext{
25 African Development Bank, Asian Development Bank, European Development Bank for Reconstruction, Inter-American Development Bank, 2018. The Future of Work: Regional Perspectives. Washington, DC: Co-publishers.
} 
mismatch, with most job seekers lacking the skills that employers require. They may have good paper qualifications but not 4IR [Fourth Industrial Revolution] skill sets. ${ }^{26}$

We know that education in Africa needs to respond to the demand to expand smallholder farming and agribusinesses (Chapter 5), which will allow African countries to enter low-end manufacturing (Chapter 9), and prepare for the rapid expanded use of modern systems and technologies (Chapter 11) as digitisation and the Fourth Industrial Revolution present new opportunities and risks for the future. The trend is away from a demand for low-skilled (and even semi-skilled) labour and towards skilled labour.

Future job requirements differ from country to country and defy easy generalisation. At a broad level, education must equip students with the skills to lead healthy, productive and meaningful lives. As the authors of the 2018 World Bank report on education explain, this means students should for instance know 'how to interpret many types of written passages - from medication labels to job offers, from bank statements to great literature'. ${ }^{27}$

The modern trend appears to be towards broader sectoral training, which includes a set of generic business and life skills rather than preparing an individual for a specific job such as being an accountant, welder, carpenter or chef. This allows the individual to more readily move from an entry-level job to a longer-term career. The most recent report from the Commission on the Future of Work refers to 'a universal entitlement to lifelong learning that enables people to acquire skills and to reskill and upskill'. Since the world of work 'begins at home' the authors also emphasise the importance of strengthening women's voice and leadership in addressing gender equality and the rural economy 'where the future of many of the world's workers lies'. ${ }^{28}$

African educators should also balance the need for academic education with vocational training. For example, the 2018 World Development Report devotes considerable attention to the need to replicate successful job skills training programmes and to the well-established extent to which most Africans aspire to academic versus technical training. In addition to advocating for Technical and Vocational Training (TVET) as a parallel education stream from secondary school onward, the World Bank advocates for

\footnotetext{
${ }^{26}$ African Center for Economic Transformation, The Future of Work in Africa-the impact of the fourth industrial revolution on job creation and skill development in Africa, 2018, p. 2.

27 The World Bank, 2018. World Development Report 2018: Learning to Realize Education's Promise. Washington, DC: The World Bank Group, p. 4.

${ }^{28}$ Global Commission on the Future of Work, 2019. Work for a Brighter Future. Geneva: International Labour Organization, p. 13.
} 
workplace training and short-term job training programmes. ${ }^{29}$ It finds that informal apprenticeships are most common in sub-Saharan Africa and offers examples from Benin, Cameroon, Cote d'Ivoire and Senegal where they account for almost $90 \%$ of the training that prepares workers for crafts jobs, as well as employment in some trades. ${ }^{30}$

Modern Germany offers a few valuable examples of technical teaching innovation, although in an entirely different setting, of course. One of the most widely acclaimed German practices is its vocational training system at secondary level schooling and the partnership that has been established, in law, between small and medium-sized companies, on the one hand, and publicly funded vocational schools on the other. The system culminates in providing a student with a certificate issued by a competent body, i.e. a chamber of industry and commerce or a chamber of crafts and trades in around 330 occupations requiring formal training in Germany in a win-win partnership between employers, unions and government. ${ }^{31}$

However, what works in highly formalised and developed Germany will not work in most of Africa, where the largest part of the economy is informal. In addition to many other challenges, the low quality of education in most sub-Saharan countries means that students may not have fully mastered the foundational skills of reading, writing, numeracy, critical thinking and problem-solving that are required before entering the vocational training stream. The World Bank refers to this as 'not just a lack of trained workers; it is a lack of readily trainable workers' ${ }^{32}$ Regardless of the continent's preparedness, digitisation and the Fourth Industrial Revolution will require a large cadre of technical skills, and the poor quality of general schooling in Africa implies that great care must be taken to ensure that students who do choose this vocational line of education have sufficient grounding.

\footnotetext{
29 The World Bank, 2018. World Development Report 2018: Learning to Realize Education's Promise. Washington, DC: The World Bank Group, p. 154.

30 Ibid., p. 155.

${ }^{31}$ Federal Ministry of Education and Research, n.d., The German Vocational Training System. [Online] Available at: https://www.bmbf.de/en/the-german-vocational-training-system-2129.html.

32 The World Bank, 2018. World Development Report 2018: Learning to Realize Education's Promise. Washington, DC: The World Bank Group, p. 9 and 157.
} 


\section{Modelling the Impact of Improved Quality, Quantity and Nature of Education Across Gender: The Boosting Education Scenario}

This section briefly sets out the interventions within the IFs modelling platform that represent ambitious but reasonable improvements in the quantity, quality and nature of education across gender in Africa. I then measure the impact of the Boosting Education scenario on the Current Path on various indices of human well-being, including on growth rates, size of economies, average incomes and inequality. In line with the reasoning that was set out in the preceding pages, the interventions simultaneously attack all aspects of poor education in Africa.

A first set of interventions improves throughput along the entire education funnel. It increases intake (or enrolment), survival and graduation rates at primary, lower secondary, upper secondary and tertiary levels, as well as the transition rates between these various levels of schooling. The impact is that Africa rockets from $82 \%$ primary school completion in 2020 to $100 \%$ primary school attendance by 2030 instead of after mid-century. This is, for sure, an extremely aggressive intervention but without a huge effort to improve this foundational aspect of Africa's development, subsequent progress on most other dimensions is virtually impossible. In the process, Africa catches up on primary school completion rates with comparable regions such as South America and South Asia within the next ten years. The interventions on lower secondary are such that the average percent of age children that complete this next level converges with the average for South Asia and South America by 2040. The increase is steep-at 24 percentage points above the Current Path in 2040 and completion rates climb from a current $51 \%$ of age-appropriate children to $85 \%$ by 2040 . Improvements for upper secondary education are of a similar aggressive nature although Africa will, by 2040, remain slightly below the 2040 rate in South Asia and South America. Whereas the Current Path forecast is for upper secondary completion rates to improve from 37 to $48 \%$, the interventions take Africa to $66 \%$. Coming from a very low base of $7 \%$ graduation rate in 2020, the Boosting Education scenario raises the rate to $18 \%$ by 2040 , some four percentage points above the Current Path forecast for that year.

Next I improve gender parity in education at primary, secondary and tertiary levels to achieve rates close to that in East Asia and the Pacific by 2050.

A third set of interventions improves the quality of education at the primary and secondary levels by about seven and six percentage points above 
the Current Path by 2040, respectively. That is enough, at primary school level, to improve quality to the level of South America by 2040. In the process African averages improve significantly above the levels approximating that for South Asia. At secondary level, where the gap between averages for South America, South Asia and Africa are smaller than with primary education, the intervention pushes African averages marginally above that for both these other two regions by 2040 .

The final set of interventions is designed with an eye on the skills requirements for the future. This is achieved by strongly boosting the ratio of vocational to academic students in secondary school as well as the share of science and engineering students at tertiary level.

There are many different ways in which to measure the impact of the Boosting Education scenario. Figure 6.2 compares the mean years of education for adults aged 20-29 years of age for the five subregions in Africa that were defined in Chapter 1. By using a youthful age cohort (20-29 years), the findings best illustrate the very rapid improvements modelled in the Boosting Education scenario. Had I used an older population cohort, such as the average educational attainment of persons older than 25 (as done in Fig. 6.1) the improvements in Africa would be less impressive when compared to the World except Africa.

Figure 6.2 compares the mean years of education for the age group 20-29 years in 2018 with the Current Path forecast for 2040 and the forecast from the Boosting Education scenario for each subregion. These are

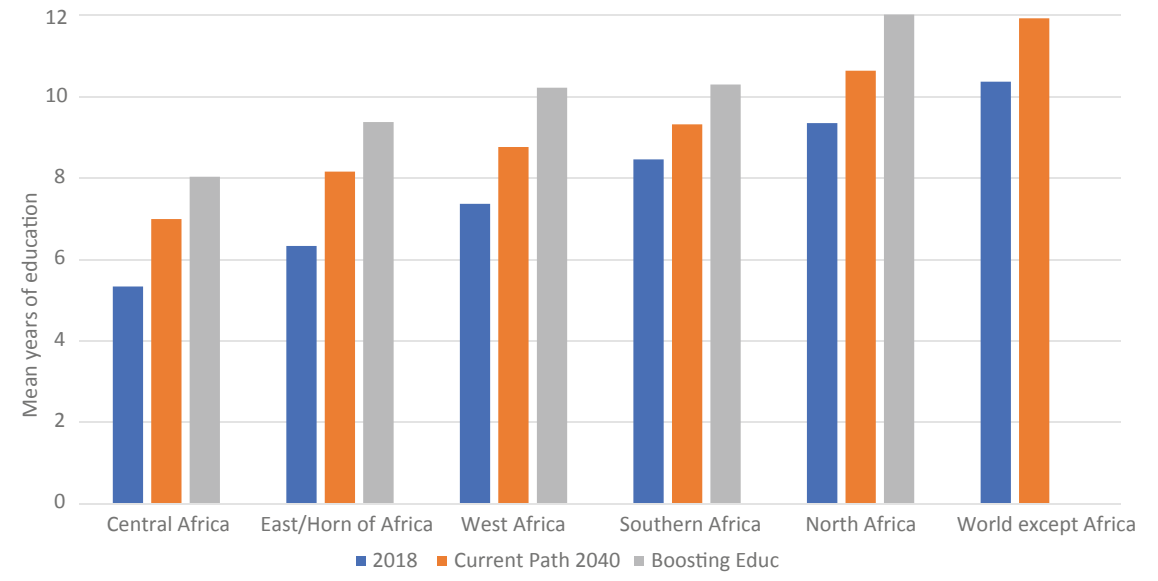

Fig. 6.2 Mean years of education for 20-29 year age cohort: 2018 and 2040 for Current Path and Boosting Education scenario (Source IFs 7.45 initializing from United Nations Population Division medium term forecast and Barro-Lee educational attainment dataset) 
compared to the Current Path forecast for the World except Africa in 2018 and 2040.

In the Boosting Education scenario and when using this young age cohort as a lens to measure progress, all five regions start closing the gap with the World except Africa but even so, Southern Africa only gets to the 2018 mean for the World except Africa by 2040! Coming off a much higher base, North Africa could actually surpass the mean in the World except Africa by 2040 . East/Horn of Africa does the best in terms of increasing mean years of education from 6.3 years in 2018 to 9.4 years in 2040. Central Africa, generally a laggard in improvements also closes the gap although to a lesser degree than others.

Had I used the older population cohort (25 years and above, used in Fig. 6.1), North Africa will not fully catch up with the mean for the World Except Africa by 2040, although narrowing the difference substantially across the forecast horizon, as does West and East/Horn of Africa. The gap between Southern Africa and the World Except Africa actually modestly increases while it remains constant for Central Africa from 2018 to 2040. Just to stand still, Central Africa has to run very hard indeed.

The impact of the Boosting Education scenario is to increase expenditure on education in Africa by an average of 0.3 percentage points of GDP by 2040 , requiring US $\$ 41$ billion of additional investment in education in that year alone. Cumulatively, Africa would spend an additional US\$264 billion from 2020 to 2040 on education. That's a lot of money but these additional costs are, in time, offset by improvements in Africa's human capital endowment. As the level of skills improves, Africa's economies start to grow more rapidly and this increase in economic growth accelerates over time.

By 2040 the difference in the GDP growth rate is between the Boosting Education and Current Path 0.5 percentage points, leading to an African economy that is US $\$ 266$ billion larger in that year compared to the 2040 Current Path forecast. By 2050 the growth difference is 0.75 percentage points and an African economy that is US\$1.4 trillion larger in that year than the Current Path forecast. ${ }^{33}$

Therefore, by spending an additional US $\$ 264$ billion on education from 2020 to 2040, the African economy will by 2040 have increased by about the same amount. But since the investment increases the stock of education, improvements accelerate over time and, inevitably, benefits accrue to more developed countries. Average levels of GDP per capita (in PPP) will increase

33 These numbers are all at market exchange rates. 
by US $\$ 90$ per person in low-income Africa by 2040 , by US $\$ 245$ for lowmiddle-income Africa and by US $\$ 393$ in upper-middle-income countries.

Just imagine the impact if Africa could simultaneously reduce the size of the annual influx of primary school children by appropriate family planning interventions as set out in Chapter 4? Reductions in the number of children entering primary school will soon cascade through the entire education system meaning more funds could be spent on the smaller cohort of children as they progress from primary to secondary, and eventually tertiary levels. In this manner the Demographic Dividend and Boosting Education scenarios could reinforce one another in a very powerful way.

Improved levels and quality of education also have a small positive effect in reducing inequality (using the Gini index) and would reduce extreme poverty by about 28 million people in 2040 (using the US $\$ 1.90$ per person extreme poverty threshold) and 64 million by 2050 .

The Boosting Education scenario could have a massive impact. But the results will not be achieved without great effort and new ways of thinking. On the one hand Africa needs to get the basics right. On the other hand the sheer magnitude of the challenge requires a very rapid uptake of modern technology to help compensate for deficits in teacher quality and numbers. I briefly discuss each of these points below.

\section{From Basics to Technology}

Models of education do not change rapidly. Because of colonialism most African countries still adhere to the Prussian model of rote education that was introduced in the eighteenth and nineteenth century and thereafter copied by most other countries. It has often, and rightly so, been criticised for being overly rigid and inflexible. But at its core we find the commitment to first teach students how to learn.

In Africa large classrooms staffed by poorly educated teachers and containing only the minimum of educational facilities are the norm. Moreover, many are attended by poor, often hungry children, many of whom have to walk several kilometres every day to school. Looking at the rather dismal state of education in Africa, the continent could clearly do with much greater order and a sense of educational purpose, particularly when it comes to improving levels of reading, writing and arithmetic and teacher attendance, and in finding ways to manage the large classes that are typical in so many schools. We desperately need to find a way to raise the bar, particularly in poorer schools. 
Certainly, each African country faces different challenges, but more parent involvement, upskilling teachers and designing teaching and learning methods that are sensitive to local conditions are central to creating functioning education systems in Africa. Not all of this requires sophisticated technology. Already a number of schooling projects require teachers to post a daily selfie by 8 am every day to prove they are in class and teaching showing how much greater use of technology can help Africa to catch up in terms of education.

Against that background, technology in the form of 5G and augmented reality could be the key ingredient to enable the progress modelled in the Boosting Education scenario.

In just a few years cell phones, tablets and even computers may all allow three-dimensional holograms as augmented reality becomes a reality. Billions of dollars are being spent on research and development by companies such as Microsoft and startups like Mojo Vision to make all of that practicable. In 2017 spending on education technology investments surpassed US $\$ 9.5$ billion, up 30\% from the year before. ${ }^{34}$

The application of new technologies could replace a teacher in front of a whiteboard (or chalkboard) with apps, gameplay and entirely new ways of teaching. For example, each student could have an artificial intelligence (AI) teaching companion in the cloud that delivers information at the optimal speed for him or her if the promise of $5 \mathrm{G}$ speeds and connectivity examined in Chapter 10 comes to Africa. In this brave new world, students will be able to consume lectures at their own pace with time in class used for discussing problems or collaborative work.

Instead of students huddling around a teacher in front of an oven to learn how to bake or around an electric motor to assemble, disassemble and repair it, each student will have his own virtual oven or motor. Using an augmented reality headset they will be able to experiment with different ingredients or take the motor apart, study each part and put it back together. Meanwhile, students studying biology will be able to dissect virtual animals and view their organs. Medical students will be able to do the same with the human body, while trainee nurses will be able to track blood flow, the digestive system and see how muscles work.

Augmented reality will make learning more immersive, exciting and effective. It could enable learners in the most isolated and disadvantaged rural areas to see and do things that they would otherwise never have the opportunity to. It is a powerful way to provide individual and flexible learning,

\footnotetext{
${ }^{34}$ Diamandis, P. H., 2018. A Model for the Future of Education. [Online] Available at: https://singul arityhub.com/2018/09/12/a-model-for-the-future-of-education-and-the-tech-shaping-it/.
} 
connecting theory with the real world. Want to get a child to learn a foreign language or to understand computer coding? Get them to play a game in that language or to experiment with coding. In tomorrow's world, understanding technology and coding will be crucial, and augmented reality and AI can help understand computation, sensors, networks, artificial intelligence, digital printing, genetic engineering and robotics, to name a few. New technology will also help with basic literacy. ${ }^{35}$

\section{Conclusion: Prioritising Education Outcomes}

The previous chapters on health (Chapter 3), demographics (Chapter 4) and agriculture (Chapter 5) reference the extent to which geography, slavery, colonialism and, after independence, the path dependency created by these histories played an important role in Africa's poor development outcomes. Determined African leadership could have changed this, but did not.

Effective education requires students who are sufficiently nourished, stimulated and cared for, capable teaching, skilled management and a government and education system that pull all of this together. Many countries in subSaharan Africa do not have these four key ingredients, and face a crisis in education which the World Bank describes as a low-learning trap. ${ }^{36}$

It is possible to escape this trap, as is demonstrated by the advances made in South Korea, China and Vietnam, but it will require a tremendous effort, political leadership, whole-of-society engagement and the use of modern technology. ${ }^{37}$

The chapter presented a supply- and demand-side view of looking at the provision of education and found that beyond basic levels of (primary) education and literacy an education system must evolve to supply many requirements while also being able to respond to changing education demands to help prepare students for the future's job requirements. The world of work requires more skilled and fewer semi- and unskilled workers.

\footnotetext{
35 For example, winners of the 2019 XPRIZE (aimed at eliminating adult illiteracy in the USA, retooling tomorrow's workforce and encouraging lifelong learning) included Learning Upgrade, which has developed an app that helps students learn English and mathematics through video, songs and gamification from kindergarten to adult education; and PeopleForWords, which offers an immersive virtual environment and gamification to improve vocabulary and comprehension.

36 The World Bank, 2018. World Development Report 2018: Learning to Realize Education's Promise. Washington, DC: The World Bank Group.

${ }^{37}$ Ibid., p. 16.
} 
There is clearly a very powerful relationship between citizens' level of education and the prosperity of nations, but it's also quite complicated. Duke University educationalist Ricardo Hausmann ${ }^{38}$ provides an apt example:

In 1998, Ghana's workforce had an average of about seven years of education and its per capita income was about $\$ 1000$. When Mexico's workforce first achieved an average of seven years of education - in 1993 - its income was over $\$ 10,000$, while France's per capita income when its workforce first got to an average of seven years of education (in 1985), was over $\$ 20,000$. These figures tell us that rich countries are rich not just because of education, and, conversely, that investing in education alone won't make you rich.

Hausmann attributes the ability to translate education and technology into growth to 'collective know-how'-the ability to apply knowledge. That, he argues, comes through imitation and repetition of tasks_learning by doing. For a country to develop and grow, it needs to provide the opportunity for learning while doing. What he does not examine, however, is the matter of the quality of the education provided in Ghana, Mexico and France, pointing to the need to dig deep when considering key relationships.

A review of the widening gap between education levels and quality when comparing Africa to the rest of the world makes it clear that much more strategic planning, innovation, investment and, most of all, leadership is required to address the continent's education backlog. The picture that emerged during this chapter's review of the general African situation and likely prospects along the Current Path forecast is depressing when compared to the progress being achieved in other regions. If the continent fails in this dimension it will fail in all others.

Education systems are notoriously slow-moving and those in most African countries are particularly so. Clearly new teaching technologies and methods must be exploited to help meet the challenges of the future. African countries will not close the gap in average levels of education compared to the rest of the world by using current systems and practices. Technology can fundamentally change the nature of education and enable the move away from brick and mortar campuses to electronic or virtual campuses that will facilitate much broader access for both students and teachers. Much of that is already possible in so-called point learning where the curious African can Google how to make, disassemble, repair, cook or understand almost anything by watching a YouTube video. I don't need to be an accredited Apple dealer with years of

\footnotetext{
${ }^{38}$ Hausmann, R., 2017. Centre for Development and Enterprise. [Online] Available at: https:// cde.org.za/wp-content/uploads/2018/06/CDE-Insight-Professor-Ricardo-Hausmann-Is-South-Africaabout-to-make-a-historic-mistake.pdf.
} 
formal training to understand how to replace and repair a smartphone. You just need the internet and a set of very small screwdrivers.

Moreover, it is imperative to find ways to channel many more students towards vocational training programmes that benefit from broader integration into the educational system and, that enable informal, virtual self-empowerment.

\section{Further Reading}

Habyarimana, James and Sabarwal, Shwetlena. 2018. Re-Kindling Learning: eReaders in Lagos. Policy Research Working Paper No. 8665. World Bank, Washington, DC. (C) World Bank. https://openknowledge.worldbank.org/handle/ 10986/30987. License: CC BY 3.0 IGO.

Launay, Robert (ed.). 2016. Islamic Education in Africa: Writing Boards and Blackboards. Indiana University Press. JSTOR. www.jstor.org/stable/j.ctt1zxz0gv. UNESCO. Director-General, 2009-2017 (Bokova, I.G.). 2017. Writer of Foreword. Cracking the Code: Girls' and Women's Education in Science, Technology, Engineering and Mathematics (STEM). UNESDOC Digital Library. https://unesdoc.unesco.org/ark:/48223/pf0000253479.locale=en. ISBN: 978-92-3-100233-5.

Open Access This chapter is licensed under the terms of the Creative Commons Attribution 4.0 International License (http://creativecommons.org/licenses/by/4.0/), which permits use, sharing, adaptation, distribution and reproduction in any medium or format, as long as you give appropriate credit to the original author(s) and the source, provide a link to the Creative Commons license and indicate if changes were made.

The images or other third party material in this chapter are included in the chapter's Creative Commons license, unless indicated otherwise in a credit line to the material. If material is not included in the chapter's Creative Commons license and your intended use is not permitted by statutory regulation or exceeds the permitted use, you will need to obtain permission directly from the copyright holder.

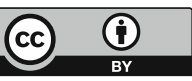

